\title{
Scrotal Swellings: Scrotal Anatomy and Physiology (Part I)
}

\author{
Ashna Malhotra ${ }^{1}$, Virendra N Sehgal ${ }^{2 *}$, Jangid B. Lal ${ }^{3}$ \\ ${ }^{1}$ K.S Hegde Medical Academy, Mangalore, India \\ ${ }^{2}$ Dermato-Venereology (Skin/VD) Center, Sehgal Nursing Home, Panchwati, Delhi \\ ${ }^{3}$ Department of Dermatology and Venereology, All India Institute of Medical Sciences and Research, New Delhi, India
}

*Corresponding author: Prof. Virendra N Sehgal, MD, FNASc, FAMS, FRAS (Lond), Dermato Venerology (Skin/VD) Center, Sehgal Nursing Home, A/6 Panchwati, Delhi-110 033(India), Tel: 011-27675363; 98101-82241/ Fax: 91-11-2767-0373;

E-mail:-drsehgal@ndf.vsnl.net.in; sehgalvn@yahoo.co.in

\section{Received date: September 16, 2015 Accepted date: February 15, $2016 \quad$ Published date: February 19, 2016}

\begin{abstract}
The narrative of applied anatomy of scrotum, a protective reservoir for the testis and related anatomical constituent of reproduction are formed, emphasizing its nerve, blood supply and lymphatic draining system. Its salient physiological characteristics too are described. The role of magnetic resonance imaging (MRI) in evaluating applied anatomical status in, particular, is define. Scrotum, plural scrotums or scrota, adjective scro'tal, a bag of skin and muscle that contains the testicles in males. The scrotum has its origin (borrowing) from Latin scr $\AA$ tum ${ }^{[1]}$.
\end{abstract}

Citation: Sehgal, V.N., et al. Scrotal swellings: Scrotal anatomy and physiology (part I). (2016) Invest Dermatol Venereol Res 2(1): 58- 60 .

DOI: $10.15436 / 2381-0858.16 .008$

\section{Introduction}

\section{Anatomy}

The scrotum ${ }^{[2]}$ is one of the vital accessory anatomical male reproductive organs which is formed by a suspended sack of skin and smooth muscle that has two-chambers, It is present in most terrestrial (earthly) male, located under the penis. It is a protective reservoir for the testis and the related anatomical structures. Asymmetry ${ }^{[3]}$ of the testis is explicit that is one testis is typically lower than the other, the functions of which is to avoid compression in the event of an impact. Classically the left testis is lower in right-handed men, whereas the right testis is lower in the left handed men.

The perineal raphe is a landmark, it is a small, vertical, slightly raised ridge of scrotal skin where scrotal septum exists. It is a thin longitudinal line which runs from front to back over the entire scrotum (Fig.1 a \& b). The contains of the scrotum on the external spermatic fascia, testes, epididymis, and ductus deferens (Fig. 2 a $\&$ b). It is a distention of the perineum, and carries some abdominal tissues such as testicular artery, testicular vein, and pampinform plexus. The scrotum becomes covered with pubic hair at puberty, the secondary sex character. It is biologically homologous to the labia majora in females.

a

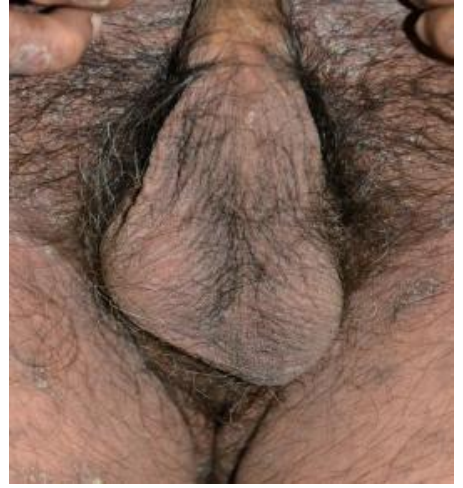

b

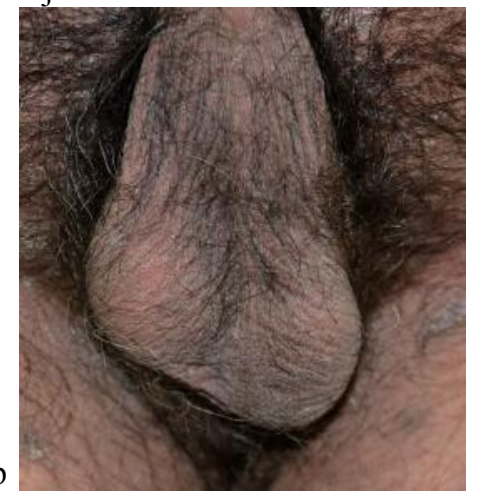

Figure 1: a \& b Displaying normal anatomy of the scrotum.

Copy rights: (C) 2016 Sehgal, V.N. This is an Open access article distributed under the terms of Creative Commons Attribution 4.0 International License. 


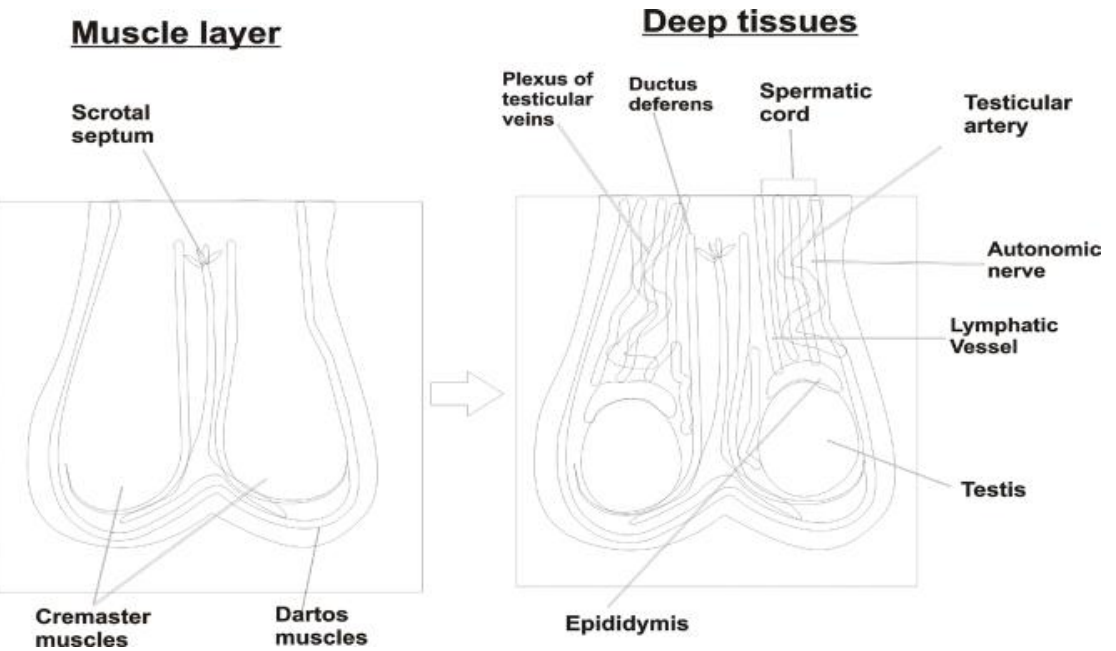

Figure 2: a \& b Defining anatomical constituents contain there in the scrotum.

Besides, the preceding narrative it is worthwhile to recall several anatomical constituents like appendix of epididymidis, cavity of tunical albuginea, cremaster muscle, dartos, ductus deferens, efferent ductules, epididymis, leydig cell, lobule of testes, paradidymis, rete testes, scrotal septum, seminiferous tubule, sertoli cell, spermatic cord, testes, tunica albuginea of testis, tunica vaginalis parietal layer, tunica vaginalis visceral layer, tunica vasculosa testis, and vas deferens, forming a comprehensive scrotal $\operatorname{sac}^{[4-6]}$.

\section{Magnetic resonance imaging (MRI)}

High-resolution MRI with a surface coil has been recommended to evaluate the normal anatomy of the scrotum. The high contrast and spatial resolution, coupled with the wide field of view, and absence of ionizing radiation, make MRI ideal for the spermatic canal, and inguinal regions for both could be visualized within the same field of view. Signal intensity differences in the testis, epididymis, tunica albuginea, fluid, fat, and spermatic cord allows for clear delineation of the afore mentioned structures ${ }^{[7]}$.

A normal testis has homogeneous texture of high signal intensity on fat-suppressed T2-weighted image, and covered with the tunica albuginea, and the visceral layer of tunica vaginalis which are seen as a thin stripe of low signal intensity. Whereas, the epididymis, shows intermediate signal intensity lower than that of the testis on FST2-weighted image. Fibrous septa dividing seminiferous lobules are seen as low signal intensity and prominent on heavily T2-weighted image, especially in infertility ${ }^{[8]}$.

Nerve supply: Scrotal surface for the purpose is divided into antero-lateral, supplied by genital branch of genitor- femoral nerve, anterior supplied by anterior scrotal nerves, a branch of illoinguinal nerve, posterior by posterial scrotal nerve, a branch of perineal nerve, while its inferior surface is supplied by perineal branches of posterior femoral cutaneous nerve ${ }^{[9]}$.

Blood supply: The blood vessels of the scrotum are anterior and Posterior scrotal artery, and Testicular vein ${ }^{[9]}$.

Integument: Scrotal Integument is relatively thin and shows a thick underlying fascia, the tunica dartos. It is composed of skin associated tissues namely hair, sebaceous glands, Apocrine sweat glands and Smooth muscles. The skin on the scrotum is pigmented compared to the rest of the body. The septum is a connective tissue membrane dividing the scrotum into two cavities ${ }^{[9]}$.

Lymphatic system: It is formed by lymphatic vessels namely superficial inguinal lymph nodes, he superficial Subinguinal Glands (lymphoglandulæ subinguinales superficiales, and the deep subinguinal Glands lymphoglandulæ subinguinales profunae ${ }^{[10]}$.

Embryology, Growth and development: The scrotum is homologous to the labia minora and labia majora. The development of reproductive organs and tissues in females and males, begin during the $5^{\text {th }}$ week after fertilization. The gonadal ridge grows behind the peritoneal membrane. By the $6^{\text {th }}$ week, string-like tissues, the primary sex cords form within the enlarging gonadal ridge. Externally, a swelling the genital tubercule, appears over the cloacal membrane. Until the $8^{\text {th }}$ week after fertilization, the reproductive organs do not appear to be different between the male and female, and are called in-differentiated. Testosterone secretion starts during the $8^{\text {th }}$ week, reaches peak levels at $13^{\text {th }}$ week, and eventually declines to very low levels by the end of the $2^{\text {nd }}$ trimester. The testosterone causes the masculinization of the labio-scrotal folds into the scrotum. The scrotal raphe is formed at a time when the embryonic, urethral groove closes by $12^{\text {th }}$ week. Although the testes and scrotum are formed early in embryonic life, sexual maturation begins only on entering puberty, causing darkening of the skin following increased secretion of testosterone ${ }^{[11]}$.

Physiology: The scrotum regulates the temperature of the testes, and maintains it at 35 degrees Celsius $\left(35^{\circ} \mathrm{C}\right) / 95$ degrees Fahrenheit $\left(95^{\circ} \mathrm{F}\right)$, which is 2 degrees below the normal body temperature of $37^{\circ} \mathrm{C}$ or $98.6^{\circ} \mathrm{F}$ Higher temperatures may affect spermato- 
genesis $^{[12]}$. Temperature control is accomplished by the smooth muscles of the scrotum moving the testicles either closer to or further away from the abdomen dependent upon the ambient temperature, which is accomplished by the cremaster muscle in the abdomen and the dartos fasciav. Furthermore, the scrotum and testicles situated outside abdominal cavity are destined to provide additional advantage(s) that scrotum is unaffected by abdominal pressure, which may prevent the emptying of the testes before the sperm are matured sufficiently for fertilization ${ }^{[12]}$. It also protects the testes from jolts and compressions (vide supra)

Acknowledgement: This article incorporates and edit text in the public domain from the $20^{\text {th }}$ edition of Gray's Anatomy (1918) to perpetuate the impeccable contributions made by Henry Gray.

\section{References}

1. Tucker, T. G. Etymological Dictionary of Latin. (1985) (Halle (Saale) 1931, repr. Ares Publishers.

2. Scrotum. (2011) National Institutes of Health. Retrieved 6 January. 3. Anthony F.B. Genital asymmetry in men. (1997) Human Reproduction 12(1): 68-72.

4. Gray, H. Splanchnology. 3c. The Male Genital. Anatomy of the Human Body. (20th ed) (1918) Philadelphia, New York: Lea \& Febiger.

5. Gray's Anatomy: The Anatomical Basis of Clinical Practice $\left(40^{\text {th }}\right.$ ed.) (2008) Churchill-Livingstone: Elsevier.

6. Snell, R.S. Structures of the Anterior Abdominal Wall: Scrotum, Testis, and Epididymides. Clinical Anatomy for Medical Students. $6^{\text {th }}$ ed. (2000). Philadelphia: Lippincott Williams \& Wilkins 153-157.

7. Baker, L.L., Hajek, P.C., Burkhard, T.K., et al. MR imaging of the scrotum: normal anatomy. (1987) Radiology 163(1): 89-92.

8. Watanabe Y. Scrotal Anatomy at MRI. (2012) Scrotal Pathology Part of the series Medical Radiology 55-66.

9. Moore, K.L., Agur, A.M. Essential Clinical Anatomy, Third Edition. (2007) Lippincott Williams \& Wilkins 132.

10. Gray, H. Anatomy of the Human Body: VIII. The Lymphatic System - The Lymphatics of the Lower Extremity. (1918).

11. Hill, M.A. Embryology Genital System Development. (2016) Retrieved September 25, 2015.

12. Van De Graaff, K.M., Fox, S.I. Concepts of Human Anatomy and Physiology. (1998) Dubuque, Iowa: William C. Brown Publishers. 